\title{
THE SPECIFICS OF POSTMODERNISM IN THE NOVEL BY VICTOR PELEVIN “GENERATION P"
}

\section{Feruzabonu E. Tagoyeva}

Master Student Bukhara State University, Uzbekistan

\section{ABSTRACT}

The subject of the research within the framework of this article is the methods of intertextuality in the advertising slogans of the novel, the play of phraseological units and "alien styles".

KEYWORDS: - Postmodernism, intertextuality, slogans, copyrights, phraseologism, "alien styles", metamorphoses, eclecticism.

\section{INTRODUCTION}

The terms "postmodern" and "postmodernism" have been of particular interest and fascinating (but also provocative) since the 1960s ambivalence within a huge section of the humanities and arts. This interest is caused by several significant phenomena within the framework of different areas of culture - mainly history, art, philosophy and theoretical literary criticism.

The literature of postmodernism is much more complex than one might imagine at first glance. This is a kind of anti-system in which the ideas expressed by the author and the heroes are ambivalent, that is, the path to consciousness lies through emptiness, negation, which the reader fills with images and meanings that are convenient for him. The freedom given to the reader is his own limitation and an eternal question.

Postmodern literature has neither definition, nor characteristics, nor any obligatory attributes at all. Its main problem is that the neologisms proposed by postmodernism can be properly understood and accepted only by postmodernism itself, that is, the perceiving consciousness must also be postmodern. In other words, often the author's occasionalisms cannot be used outside a certain context, since their meaning will be lost.

However, it should be emphasized that 
CURRENT RESEARCH JOURNAL OF PEDAGOGICS 2(12): 72-76, December

2021 DOI: https://doi.org/10.37547/pedagogics-crjp-02-12-15

ISSN 2767-3278

(C)2021 Master Journals

Crossref do: 81 Google

Accepted 17 thecember, 2021 \& Published 22 ${ }^{\text {th }}$ December, 2021

postmodernism (and, accordingly, poststructuralism) is not a homogeneous flow, phenomenon, discourse, since its worldview is based on pluralism of thinking and the absence of a single organizing center, i.e., on decentration.

\section{THE MAIN FINDINGS AND RESULTS}

One of the main features of postmodern novels is their intertextuality, in other words, the postmodern text is woven from hundreds of other texts. In this regard, many researchers note that "the main task of a translator in the case of translation of postmodern texts is the recognition of various types of intertextual connections, their deciphering and transmission in the target language" [Nesterova, Popova]. In addition, the language game is an integral part of this literary movement.

"Postmodernism is characterized by total irony, playfulness, as well as the eschatological mood of the end of the millennium and" déjà vu ", the effect of which is based on " literary recollection", i.e. on an intertextual strategy, notes E.Yu. Popov. "All the above-mentioned features have found a vivid expression in the work of Viktor Pelevin" [Popov].

Viktor Pelevin is a prominent representative of Russian postmodernism, the author of cult novels such as "Omon Ra", "Chapaev and Emptiness", and "Generation P" laureate of numerous literary awards, including "Small Booker" (1993), "National Bestseller" (2004), "Big Book" (2010), Andrey Bely Prize (2017).

Generation $\mathrm{P}$ is a postmodern novel about a generation of Russians who matured and took shape during the political and economic reforms of the 1990s. The novel is set in Moscow. The protagonist of the novel is Vavilen Tatarsky, an intelligent young man graduated from the Literary Institute, he received his unusual name from his father - a fan of Vasily Aksyonov and Vladimir Lenin. Tatarsky is a collective image of the "generation P" - the generation of the seventies.

Thanks to chance, he gets into the world of advertising and discovers his talent - to compose advertising slogans. Thus, he becomes first a copywriter, then a "creator". Vavilen's task is to adapt the advertising of foreign goods to the domestic mentality. Then Tatarsky becomes the creator of television reality, replacing the surrounding reality. Tatarsky participates in the creation of teleimages of statesmen and the country's political life itself with the help of computer technology. However, he is constantly tormented by "eternal questions", who controls this, and in the end he becomes a living god, the earthly husband of the goddess Ishtar [4].

The topic of "Generetion P" is quite complex and includes several components - this is mythology, and the influence of advertising on the minds of people, and the role of drugs, and even a conspiracy theory (the world is ruled by advertisers).

\section{Intertextuality in the advertising slogans of the novel}

For Viktor Pelevin in his early work, to which we refer the novel "Generetion P", banter becomes the most characteristic technique of double coding. Note that "banter is a carnivalized form of criticism, which is realized either through direct defamation of the object of banter, or through exaggeration and bringing to the point of absurdity its characteristic features and sides, often positive, and, as a result, their separation from the image of the object, as a result of which realism the image in the eyes of the audience disintegrates, and after it the original image itself collapses. "

This can be easily traced by the example of advertising slogans and copyrights created by the protagonist of the work, Vavilenom Tatarsky, and which are, as it were, a symbolic dominant of 
CURRENT RESEARCH JOURNAL OF PEDAGOGICS 2(12): 72-76, December

2021 DOI: https://doi.org/10.37547/pedagogics-crjp-02-12-15

ISSN 2767-3278

(C)2021 Master Journals

Crossref do: 81 Google

Accepted 17 thecember, 2021 \& Published 22 ${ }^{\text {th }}$ December, 2021

the entire text, a work in a work. The aesthetics of deliberate exaggeration is a reflection of the unnaturalness and absurdity of both commodity myths of a consumer society, as well as a simulacrum of money in general, which is the embodiment of the absolutization of the material side of life, its own Rodan laws of being: "Everything is for sale: love, art, planet, Earth, you, me" [4, c.3].

In fact, Viktor Pelevin projects the situation of the commodity myth onto human life. Pelevin introduces codes into advertising texts that are typical of the cultural paradigm of the Russian consciousness. Sometimes the author will combine the syllable with a coveted song, while being sure to recognize and beloved by the people. For example, "I drank a birch Sprite in a spring forest" [5, p. 157]. He does not avoid the use of the painting for his advertising texts and ditties: "Ivan Ilyich and I worked on a diesel engine. I am mad, and he is mad and we have a "Diesel" sleep ... whether! " [5, p. 171] or "On March 8, I'll give Mane a necklace to De Birc and earrings from Armani - then it will be for a... cy!" $[5$, p. 174]. This is necessary in order to show that advertising, and together with it, commodity relations, have penetrated not only into our daily life, but also into the holy of holies for any bearer of Russian culture - into the language.

Following the logic that language seriously determines our thinking, the author of the novel comes to the conclusion that these metamorphoses, in turn, lead to the fact that a person gradually begins to identify himself with a certain set of goods and values that he can acquire in life. Sociologists who study the influence of advertising on society call such a change in consciousness - "brand reality". "The subject gradually ceases to perceive the people around him by their height, skin color or age, for him the welfare of a social competitor comes to the fore. Of course, the material status is determined through certain symbols - a car, a house, a yacht, at worst, new sneakers or a hair clip" $[4$, p. 451].

To be frank, the difference between real and Pelevin's advertising texts is only that Viktor Olegovich in one way or another exaggerates what he had invented and makes it a little more grotesque in order to demonstrate to the reader what abyss of mythology, unreality and dehumanization he is plunging freshly into. acquired freedom to trade whatever you want and say what you want. In fact, if you develop this idea to its logical end, it turns out that as the original, true, immanent values, ideas, principles and concepts are displaced under the influence of commodity myths, a person loses himself, his true "I" and turns into a walking set of assimilated simulacra ...

"The absurdity, the absurdity of advertising texts inscribed in a storyline no less strange from the point of view of pre-modernist logic, gives the reader a look at modern life from the outside and the owner is happy. " In fact, it only contributes to the loss of one's own "I". "A person without spiritual and moral values is nothing. It is zero, even less than zero. He is a piece of meat, living only for the sake of not being materially dependent on anyone, but at the same time, intellectually and spiritually to become a work "[4, p. 151].

The game of phraseological units and "alien styles" in the novel.

Speaking about the language game, it should be noted that in Victor Pelevin's novel it manifests itself, for example, in mixing styles and free handling of phraseological units. Fixed expressions are repeatedly used in scripts and slogans written by the main character of the work - Vavilen Tatarsky. An example is the statement "The genus comes and the genus leaves, and the earth abides forever", which organically fits into the advertising of a confectionery plant in order to emphasize the 
CURRENT RESEARCH JOURNAL OF PEDAGOGICS 2(12): 72-76, December

2021 DOI: https://doi.org/10.37547/pedagogics-crjp-02-12-15

ISSN 2767-3278

(C)2021 Master Journals

\section{Crossref do) 8 Google}

Accepted 17th December, 2021 \& Published 22 ${ }^{\text {th }}$ December, 2021

fragility of the existing world and the presence of only a limited number of permanent things (in the original, such permanent things can be attributed to the earth, in the video - a confectionery plant).

However, after the client who ordered the video is killed, interesting metamorphoses take place with this dictum: "The clan comes, and the clan leaves, Tatarsky thought philosophically," and your shirt is closer to your body "[Pelevin, p. 29]. Thus, there is a combination of the quotation about the family and the proverb "Your shirt is closer to your body", and at the same time the saying only strengthens the meaning of the proverb: your aspirations and desires will always be higher than the aspirations and desires of others.

Another example of the use of phraseological units in advertising is the saying "Money does not smell". So, in the advertisement of the new fragrance "Hugo Boss" created by Vavilen Tatarsky, the imagery of this phraseological unit is violated and it is transformed into a diametrically opposite statement: "Money smells".

In this case, we are not talking about the fact that the way of getting money is not important, but about the availability of a new cologne of a wellknown company only to rich and famous people. It is significant that a catch phrase referring to high style is used in advertising cologne - a household item, everyday, and this helps to create a certain comic effect, to emphasize the absurdity of the consumer society:

"The absurdity, the absurdity of advertising texts, inscribed in a storyline no less strange from the point of view of pre-modernist logic, gives the reader a glimpse and understanding of the absurdity of moving away from his spiritual origin towards inanimate things, supposedly capable of solving all problems and making the owner happy" [ Kugaevsky].
The destruction of imagery is also present when using the phraseologism "dull, like in a tank", which characterizes a hopeless business or a question / request that remains unanswered. In Viktor Pelevin's novel, we meet only the first part of it "like in a tank" when describing the stall in which Vavilen Tatarsky worked even before joining the advertising business: "It was half dark and cool in the stall, like in a tank ..." [Pelevin]. As a result, only a direct meaning remains, and we see a comparison of a small, uncomfortable room with a tank.

Perhaps one of the most interesting moments associated with phraseological units in the novel "Generation" P "" can be considered the creation of new statements. Vavilen Tatarsky, for example, speaking about a huge number of advertising agencies, does not use the wellknown expression "like mushrooms after the rain", but one invented by him "like coffins after the leader" [Pelevin]. Indeed, in the Soviet Union, whose existence began with a revolution and a civil war, and then was marked by Stalinist repressions, it was a comparison with a large number of deaths caused by people in power that was quite understandable, but mushrooms in the 90s of the XX century were people almost never collected.

A wide variety of played "alien styles" are contained in the novel "Generation $\Pi "$ ". Here you can talk about a kind of eclecticism of styles: advertising, colloquial, scientific, slang, television and newspaper, anecdotal, the language of the "new Russians", saturated with barbarism and jargon. The style of the novel bears a vivid imprint of the postmodern era, about which Pelevin writes: "And then the unexpected happened. With eternity, to which Tatarsky decided to devote his labors and days, something also began to happen. <...> Not that they have changed their previous views, no. The space itself, where these former gazes were directed (the gaze is always directed somewhere), began 
CURRENT RESEARCH JOURNAL OF PEDAGOGICS 2(12): 72-76, December

2021 DOI: https://doi.org/10.37547/pedagogics-crjp-02-12-15

ISSN 2767-3278

(C)2021 Master Journals

Crossref do: 81 Google

Accepted 17 thecember, 2021 \& Published 22 ${ }^{\text {th }}$ December, 2021

to curl up and disappear until only a microscopic speck on the windshield of the mind remained of it. "

Time itself is reflected and expressed in a language where English and Russian are mixed, high and vulgar, scientific and slang, complex and primitive, eternal and momentary.

The novel describes a huge number of advertised imaginary and existing in reality only for the "new Russian" products, about which the author sneers: "All trademarks mentioned in the text are the property of their respected owners, and all rights are reserved." $\mathrm{He}$ also laughs at himself (pastiche style): "The opinions of the author may not coincide with his point of view."

The "alien style" technique is also constantly encountered in the novel by Viktor Pelevin "Generation ח”. Most researchers rightly consider the organic assimilation of the game cultural tradition at the level of the language of a work of art to be a feature of the writer's idiostyle. The technique of stylistic quotation, or stylistic play imitation of someone else's style, is used by the writer everywhere.

\section{Conclusion}

Playing with "alien styles" allows Viktor Pelevin, who closely observes the linguistic processes, to create a vivid modern language of his characters. V. Pelevin, as a true postmodernist, never feels constrained in linguistic means, he freely uses all available stylistic layers - from "high" to the most marginal. It is the language of V. Pelevin's works that most accurately reflects the current linguistic situation, however, the stylistics of his texts is by no means determined by ease of perception, but by ornamentation and intertextuality.
1. Beigbeder F. 99 francs. $M$.: Inostranka, 2007.396s.

2. Kugaevsky A. Artistic interpretation of commodity discourse in Victor Pelevin's novel "Generation P" // Criticism and semiotics. 9.Novosibirsk, 2009.S. 144-157

3. Likhina N.E. Actual problems of modern Russian literature. Postmodernism. Kaliningrad, 1997.

4. Pelevin V. Generation "P". - M. 1999. URL .: http://pelevin.nov.ru/romans/pe-genp/

5. Pelevin V. Generation "P". M .: Eksmo 2003.352s.

\section{REFERENCES}

